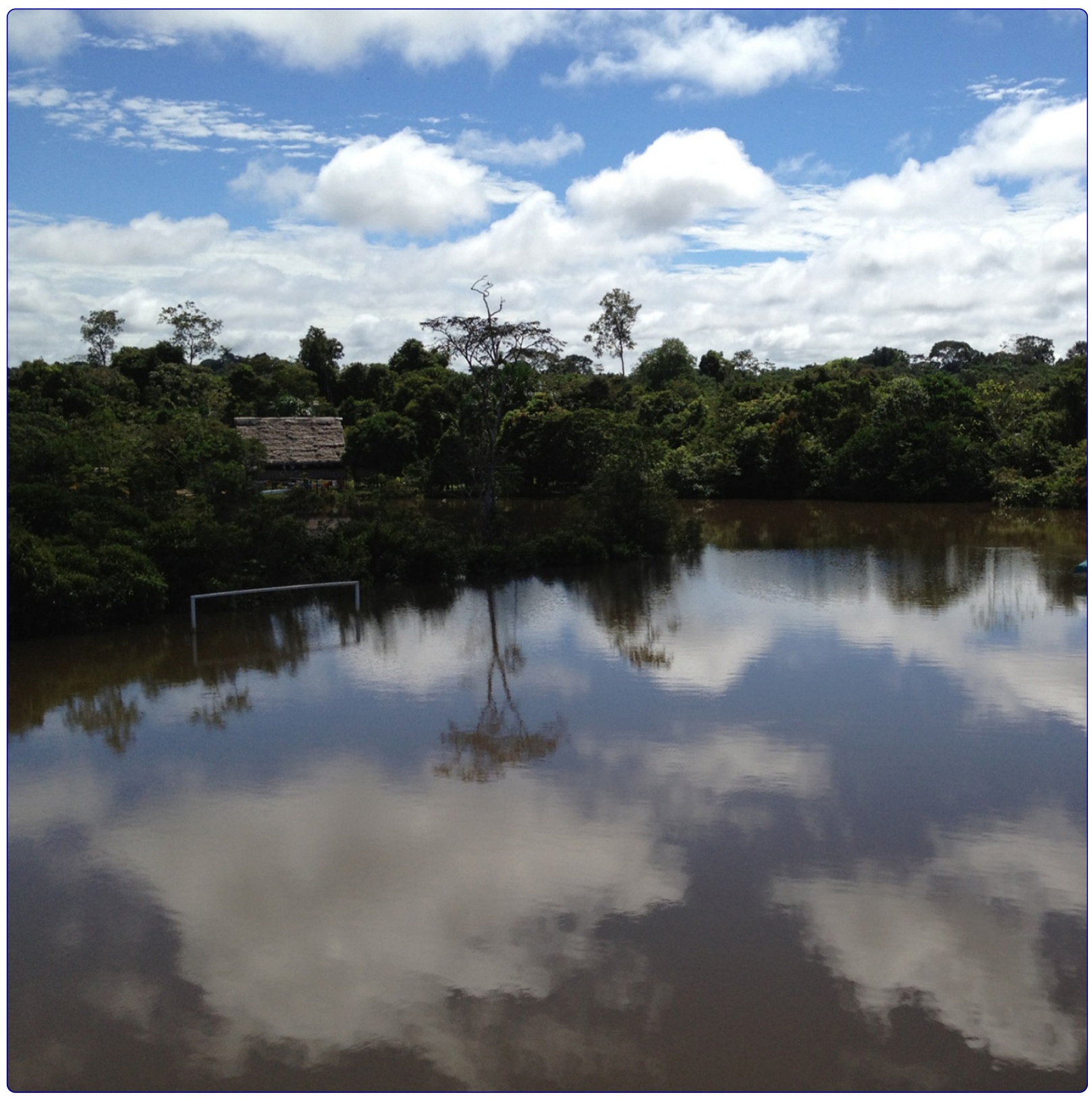

Relationship of regulatory T cells to Plasmodium falciparum malaria symptomatology in a hypoendemic region

Torres et al.

() Biomed Central 


\title{
Relationship of regulatory T cells to Plasmodium falciparum malaria symptomatology in a hypoendemic region
}

\author{
Katherine J Torres ${ }^{1,2}$, Elizabeth Villasis ${ }^{1,2}$, Jorge Bendezú ${ }^{1,2}$, José Chauca ${ }^{1}$, Joseph M Vinetz ${ }^{1,2,3^{*}}$
} and Dionicia Gamboa ${ }^{1,2^{*}}$

\begin{abstract}
Background: Previous data have suggested that regulatory T cells (Tregs) balance protective immune responses with immune mediated pathology in malaria. This study aimed to determine to test the hypothesis that Treg proportions or absolute levels are associated with parasitaemia and malaria symptoms.

Methods: Treg cells were quantified by flow cytometry as CD4+ CD25+, Foxp3+, CD127 low $T$ cells. Three patient groups were assessed: patients with symptomatic Plasmodium falciparum malaria (S), subjects with asymptomatic P. falciparum parasitaemia (AS) and uninfected control individuals (C).

Results: S, AS and C groups had similar absolute numbers and percentage of Tregs (3.9\%, 3.5\% and 3.5\% respectively). Levels of parasitaemia were not associated with Treg percentage $(p=0.47)$.

Conclusion: Neither relative nor absolute regulatory T cell numbers were found to be associated with malariarelated symptomatology in this study. Immune mechanisms other than Tregs are likely to be responsible for the state of asymptomatic $P$. falciparum parasitaemia in the Peruvian Amazon; but further study to explore these mechanisms is needed.
\end{abstract}

Keywords: Regulatory T cells, Asymptomatic, Symptomatic

\section{Background}

Plasmodium falciparum-infected individuals show a wide spectrum of clinical manifestations that range from a state of asymptomatic infection to severe life-threatening forms, such as hyperparasitaemia, hypoglycaemia, cerebral malaria, respiratory distress, and vital organ dysfunction $[1,2]$. In recent years, the concept of asymptomatic parasitaemia and its potential interaction with the human immune system to malaria infection has emerged on the forefront of why some individuals are able to control the infection with lack of symptoms [3-6]. This concept implies that individuals with low parasitaemia, in the absence of clinical symptoms (i.e. fever, headache, chills, malaise, etc.)

\footnotetext{
* Correspondence: jvinetz@ac.ucsd.edu; dionigamboa@yahoo.com 'Instituto de Medicina Tropical "Alexander Von Humboldt", Universidad Peruana, Cayetano Heredia, AP 4314, Lima 100, Peru

${ }^{2}$ Departamento de Ciencias Celulares y Moleculares, Laboratorios de Investigación y Desarrollo,Facultad de Ciencias y Filosofía, Universidad Peruana Cayetano Heredia, AP 4314, Lima 100, Peru

Full list of author information is available at the end of the article
}

evidence that down-regulation simultaneously of both the innate immune system and antigen-specific dependent immunity is obvious $[3,5,6]$.

Elevated levels of circulating tumor necrosis factor (TNF), interleukin-6 (IL-6), IL-12, IL-1 $\beta$, and IL-10 have been reported to correlate with malaria disease severity and with fatal outcomes $[7,8]$; the behaviour of these cytokines in asymptomatic parasitaemia remains unknown. Regardless, the mechanisms by which acquired and innate immune mechanisms lead to the state of asymptomatic malaria parasitaemia remain unexplored.

That much of the symptomatology of malaria infection seems to be immune-mediated implies that protective versus pathological immune responses are tightly regulated. Interest has recently arisen in mechanisms of immune regulation mediated by $\mathrm{CD} 4^{+}, \mathrm{CD}_{2} 5^{+}$, FoxP3 ${ }^{+}$ regulatory $\mathrm{T}$ cells (Tregs). This $\mathrm{T}$-cell subset has been shown to play an important role in maintaining immune homeostasis and controlling excessive immune responses 
[7]. These cells have been reported to suppress cellular immune responses through direct contact with immune effectors cells and by production of regulatory cytokines, including TGF-ß and IL-10 [7].

Previous work has shown that Tregs significantly modify the host response to malarial infection including modulation of responses to $P$. falciparum pro-inflammatory moieties such as GPI anchors and DNA-adsorbed to haemozoin [7,9], and self-regulation moderated by the broader immunological environment. In turn, the host response to malarial infection is influenced by both the genetic background of the host and co-infection with other pathogens $[9,10]$. Tregs have been reported to modify blood-stage infection in vivo in humans including higher parasite growth rates [10-12] and elevated production of transforming growth factor-beta (TGF- $\beta$ ) and IL-10 [11] that lead to down-modulation of inflammatory responses mediated through interferon-gamma (IFN- $\gamma$ ) $[5,11]$.

In the low transmission setting of Amazonia, asymptomatic malaria parasitaemia is surprisingly common $[3,6,11,13,14]$. This paradoxical pattern stands in contrast to high transmission regions where acquired immunity is manifested by asymptomatic parasitaemia that typically takes years and intense seasonal or continuous transmission to develop. Important exceptions have been demonstrated when malaria-naïve migrants move as adults to high transmission regions [13]. Hence, there is an abundance of asymptomatic malaria infection, the functional consequences of which remain unclear and relatively neglected. In this particular study in general, the hypothesis that the state of asymptomatic malaria parasite involves both antigen-specific acquired immunity and down-regulation of pro-inflammatory innate immune responses that may promote the ability of asymptomatic reservoirs to transmit infection to vector mosquitoes.

Understanding mechanisms of clinical immunity manifested by asymptomatic malaria parasitaemia has emerged as a major issue in the malaria field [13]. This study aimed to test the specific hypothesis that absolute numbers of circulating Tregs contribute to maintain a state of asymptomatic malaria parasitaemia. Tregs in symptomatic and asymptomatic subjects with P. falciparum malaria-hypoendemic region of the Peruvian Amazon were studied.

\section{Methods}

\section{Study site and population}

The study was carried out in communities near Iquitos, Peru in the Amazon region. Strategies for identifying patients were as follows:

A. Passive case detection (PDC), where samples were obtained from presenting to the San Juan Bautista Health Centre in Iquitos. All samples obtained here came from symptomatic patients with uncomplicated malaria. The patients attended the Health Centre because of selfreported fever. Plasmodium falciparum infection was confirmed after light microscopic examination of stained thick and thin peripheral blood smears, and later further confirmed at the species level using a specific PCR assay [15]. Health post personnel were accurate in accurately identifying the presence of P. falciparum.

B. Active case detection (ACD), the sampling of asymptomatic parasitaemic individuals, was based on identifying collaterals. Once the identification of a symptomatic subject with $P$. falciparum infection during passive case detection, the index case's family and neighbours were visited weekly over the subsequent month to identify additional asymptomatic cases, assuming local transmission and acquisition of infection.

Furthermore, there was an ACD survey carried out in the small village of Atalaya located 6-7 hours northwest of Iquitos by motor-boat. This area was chosen as a study site because of reports of an outbreak of $P$. falciparum in March of 2010. 14 samples from symptomatic/asymptomatic individuals were obtained in this community.

Whole blood samples were collected from 26 patients with $P$. falciparum malaria, 15 with acute uncomplicated malaria (S), 11 with asymptomatic malaria (AS) and seven adults who denied a history of malaria (Controls, C). The diagnosis of $P$. falciparum malaria infection was based on the light microscopy examination of Giemsastained thick blood films. Real time polymerase chain reaction (PCR) with species-specific primers was performed on DNA isolated from dry blood samples on filter paper to verify malaria infection [15]; blood cell counts were performed using Turk's solution. All subjects had $P$. falciparum mono-infection; no subject had $P$. vivax infection identified either by peripheral blood smear or PCR.

\section{Ethical consent}

The study was approved by the Ethics Committee of Universidad Peruana Cayetano Heredia, Peru. All subjects provided written informed consent prior to enrollment.

\section{Flow cytometric analysis}

Unprocessed whole blood was shipped at ambient temperature the same day from Iquitos to Lima and processed within $8 \mathrm{hr}$ of blood draw. PBMCs were isolated from heparinized blood by density gradient centrifugation (BD Vacutainer CPT Cell Preparation Tube with sodium heparin, NJ). Regulatory cells were defined as being $\mathrm{CD}^{+}$, $\mathrm{CD} 25^{+}, \mathrm{CD} 127^{\text {low }}$ and FoxP3 by flow cytometry. PBMCs were first stained using peridinin-chlorophyll-a (PerCP)conjugated anti-CD4 and phycoerythrine (PE)-conjugated anti-CD25 monoclonal antibodies (BD Biosciences, San Jose, California, USA). After fixing and permeabilizing, the 
cells were then stained for intracellular FoxP3 using a fluorescein-isothiocyanate (FITC)-conjugated anti-FoxP3 monoclonal antibody (eBiosciences, San Diego, California, USA). Cells were analysed using a FACScalibur flow cytometer (Beckton Dickinson, Franklin Lakes, New Jersey, USA). Regulatory $\mathrm{T}$ cells were identified as CD25+ and FoxP3 + cells among CD4+ cells within the lymphocyte gate. Absolute CD4+ cell counts were performed using a 4 color single platform staining of whole blood cells (anti CD3-FITC, CD4-PE, CD45 PerCP and CD8 APC). Flow cytometry analysis used FlowJo software (V.8.5 Tree Star, Ashland, Oregon, USA).

\section{Statistical analysis}

The non-parametric Kruskal-Wallis test was used to compare the values of each variable among different groups. The Mann-Whitney $U$ test with the Bonferroni correction was used for post-hoc comparisons. The linear relationship between Treg cell percentage and peripheral parasitaemia was measured by Spearman's Rank Correlation Coefficient. The level of significance was set at a $\mathrm{P}$ value of $<0.05$ for all analyses.

\section{Results}

A significant decrease in the number of circulating lymphocytes in $S$ individuals (Table 1 ) was found to be related to $P$. falciparum, and could be related to migration to lymph nodes during acute infection as reported previously [16]. AS individuals infected with P. falciparum had more circulating leukocytes compared to $\mathrm{S}$ individuals $\left(5.7 \times 10^{9} / \mathrm{L}\right.$ and $\left.5.0 \times 10^{9} / \mathrm{L}\right)$ respectively; $p=0.002$. In contrast, $\mathrm{S}$ individuals had total leukocytes compared to $\mathrm{C}$ individuals $\left(1.41 \times 10^{9} / \mathrm{L}\right.$ and $\left.2.010^{9} / \mathrm{L}\right)$ respectively; $p=0.005$. Nonetheless, total lymphocyte counts were similar between $\mathrm{S}$ and AS individuals $\left(1.41 \times 10^{9} / \mathrm{L}\right.$ and $1.78 \times 10^{9} / \mathrm{L}$, respectively). The levels of parasitaemia were significantly different in $\mathrm{S}$ compared to AS individuals $p=0.0003$ (Table 1).

Treg cells identified by flow cytometry as $\mathrm{CD} 4^{+} \mathrm{T}$ cells expressing Foxp3, CD $25^{+}$and low levels of $\mathrm{CD} 127^{\text {low }}$ were measured and reported as a percentage of total $\mathrm{CD} 4^{+}$ $\mathrm{T}$ cells. There were no significant differences in Treg cell percentage among patients with uncomplicated $P$. falciparum malaria S (median 3.9\%), AS (median 3.5\%), and C (median 3.5\%) individuals $[H=0.613, \mathrm{df}=2, p=0.736]$ (Figure 1), or absolute Treg cell numbers between $S$ and AS patients (median $7.88 \times 10^{6} / \mathrm{L}\left[3.38-24.08 \times 10^{6} / \mathrm{L}\right]$ and median $8.66\left[5.01-16.06 \times 10^{6} / \mathrm{L}\right]$, respectively) (Table 1), according to the Kruskal-Wallis test.

The percentage of Tregs from $\mathrm{S}$ and AS patients was compared with peripheral parasitaemia. No significant linear correlation between Treg percentage and parasitaemia (parasites $/ \mathrm{ml}$ ) was found $[\mathrm{r}=0.02, p=0.47]$ (Figure 2).

\section{Discussion}

This study showed that Symptomatic (S), Asymptomatic (AS) and Control (C) groups had similar absolute numbers and percentage of Tregs in peripheral blood, 3.9\%, $3.5 \%$ and $3.5 \%$ respectively, and a relationship between Treg percentage and parasitaemia was not found (Figures 1 and 2). Therefore, there was no support for the hypothesis that in the P. falciparum hypoendemic region of the Peruvian Amazon, absolute or relative numbers of Tregs relates to malaria symptomatology. These results stand in contrast to previous studies in mouse and from humans in other malaria regions [4,9,17-20], where the expansion of Tregs was found to be significantly associated with increased parasite load and development of clinical malaria.

Some studies have compared numbers of Tregs with severe or uncomplicated malaria, and found also increased number of Tregs during convalescence negatively

Table 1 Demographic and clinical characteristics of study participants

\begin{tabular}{|c|c|c|c|c|c|c|}
\hline \multicolumn{7}{|c|}{ Plasmodium falciparum infection status } \\
\hline \multirow[t]{2}{*}{ Characteristics } & \multirow{2}{*}{$\begin{array}{l}\text { Symptomatic } \\
\text { (S) }\end{array}$} & \multirow{2}{*}{$\begin{array}{l}\text { Asymptomatic } \\
\text { (AS) }\end{array}$} & \multirow{2}{*}{$\frac{\text { Control }}{(\mathrm{C})}$} & \multicolumn{3}{|l|}{$P$ value } \\
\hline & & & & (C vs. S) & (C vs. AS) & (S vs. AS) \\
\hline No. of subjects & $n=15$ & $n=11$ & $\mathrm{n}=7$ & & & \\
\hline Gender (\% male) & $60.00 \%$ & $55.55 \%$ & $71.43 \%$ & & & \\
\hline Median age (year) [range] & $28[9-59]$ & $17[12-41]$ & $30[22-34]$ & 0.589 & 0.389 & 0.42 \\
\hline No. of Leukocytes $\left(10^{9} / \mathrm{L}\right)^{*}$ & $5.0[4.3-6.0]$ & $5.7[5.1-7.6]$ & $5.5[4.2-6.5]$ & 0.203 & 0.276 & 0.002 \\
\hline No. of Lymphocytes $\left(10^{9} / L\right)^{*}$ & $1.41[0.93-2.1]$ & $1.78[1.28-2.58]$ & $2.0[1.4-2.6]$ & 0.0054 & 0.389 & 0.018 \\
\hline No. of Tregs $\left(10^{6} / L\right)^{*}$ & $7.88[3.38-24.08]$ & $8.66[5.01-16.06]$ & $11.09[8.88-11.62]$ & 0.29 & 0.297 & 0.979 \\
\hline Parasitaemia** & $5999[71-52,900]$ & 1 [1-2874] & NA & NA & NA & 0.0003 \\
\hline
\end{tabular}

*Median [range] and means, the value of 50 percentile [min - max].

${ }^{* *} \mathrm{~N}^{\circ}$ of parasites $\mathrm{ml}^{-1}$.

$P$ values are from Mann-Whitney $U$ test (to compare two non-parametric group distributions by rank).

The proportion of male gender was compared by Chi-square test. Only for gender the test was the Chi-square test used. 


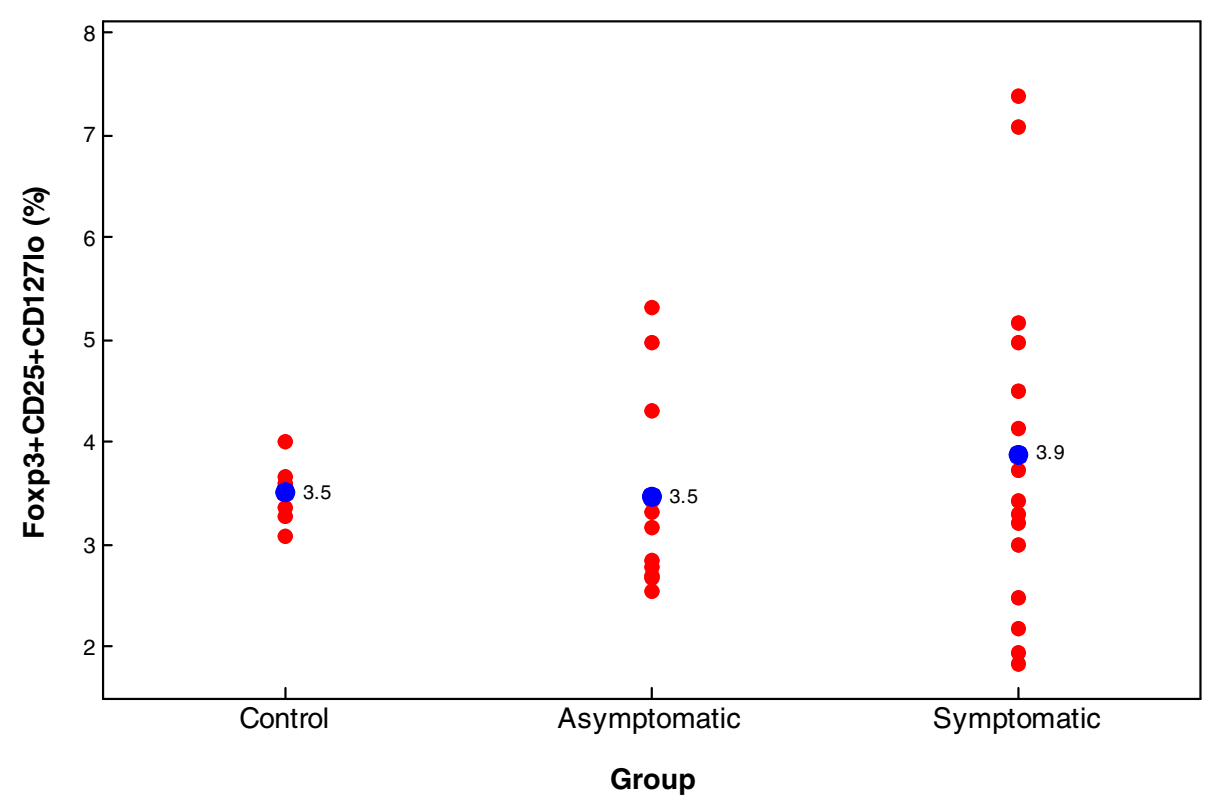

Figure 1 Percentage of Tregs in control, symptomatic and asymptomatic subjects. The blue dots indicates the median. No statistically significant differences were found among groups.

associated with the magnitude of Th1 memory response in children [21], and the increase associated with parasite biomass in severe but not complicated cases in adults [22]. Studying other species, adults with uncomplicated $P$. vivax infections were also found to have increased proportions of $\mathrm{CD}^{+}{ }^{+} \mathrm{CD} 25^{+}$Foxp $^{+}$Treg cells in Thailand [23] and Brazil [24]. A different result was demonstrated by Gonçalves et al. [25] who found that malaria patients from hypo- to meso-endemic region had lower absolute numbers of Treg cells than controls related to lower overall $\mathrm{CD}^{+}$cell counts. In contrast to our observations, this previous study showed that the CD25 ${ }^{+}$

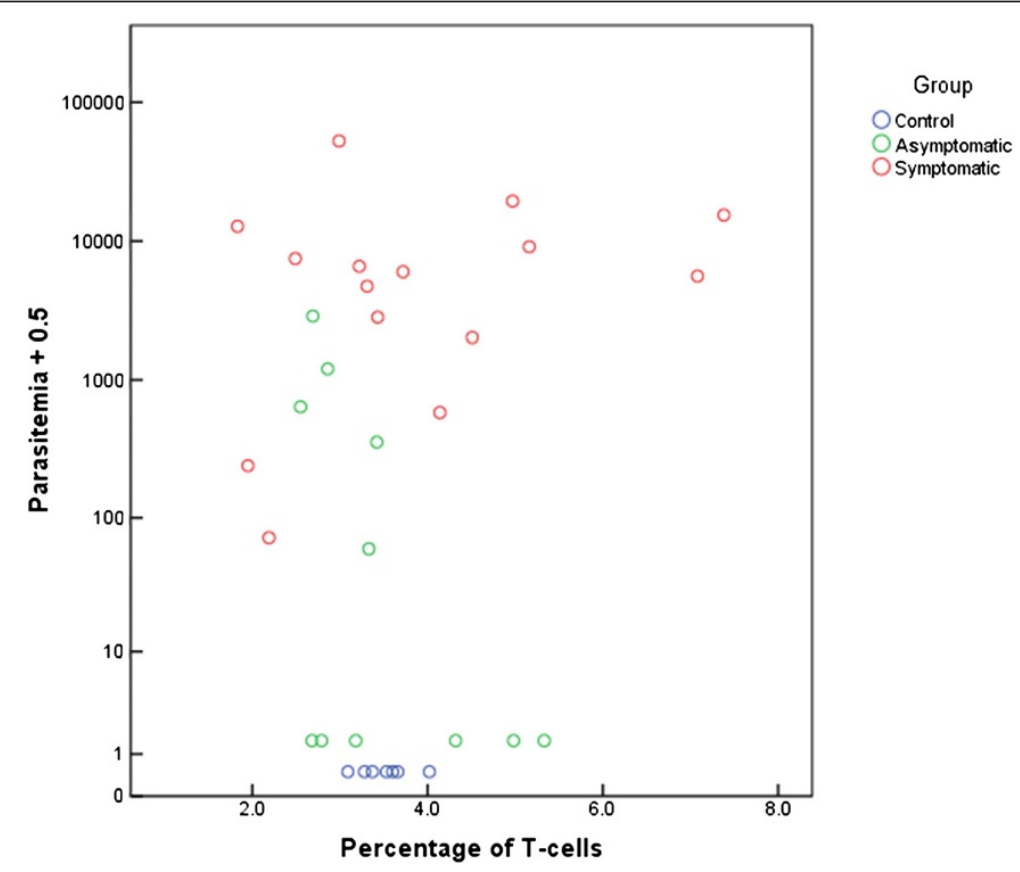

Figure 2 Correlation of parasitaemia and Tregs. Variation of blood parasitaemia level for P. falciparum according to the percentage of Tregs on control, asymptomatic and asymptomatic subjects. 
Foxp $^{+}$Treg cell counts were inversely proportional to level of parasitaemia [26].

These results showed that the absolute numbers and proportion of Tregs were similar among symptomatic and asymptomatic groups despite a higher parasitaemia in S group vs. AS group, confirming that the relationship between number of parasites and Tregs activity is still not clear. Therefore, at least in the context of the hypoendemic setting, total numbers of Tregs are not implicated in the symptomatology or control of parasite proliferation. These results agree with previous reports that showed a more efficient Th1 and Th2 response toward $P$. falciparum antigens [27]. A study carried out in Fulani, a West African ethnic group with low susceptibility to malaria, reported that this population's PBMCs express higher amounts of RNA for several Th1 and Th2 related genes but gene expression of FOXP3 and cytotoxic $\mathrm{T}$ lymphocyte antigen 4 (CTLA4) was markedly lower [28]. These results, compared to other studies, suggest that activity of Tregs in this ethnic group is not involved in regulatory response against malaria.

Although the data presented here did not include analysis of cytokines associated with Tregs, antigen-specific Tregs or possibly a lower expression of molecules involved in Treg cell mediated modulation of immune responses might contribute to the control of symptoms related to symptomatic vs. asymptomatic parasitaemia.

Little is known about characteristics of the malaria parasites themselves associated with the state of asymptomatic infections. A recent study of asymptomatic infected children found an increased tumor necrosis factor receptor type II (TNFRII) expression on Tregs confirming the activation of these cells even in subclinical parasitaemia [29].

The lack of relationship of number or proportion of Tregs to symptomatology in the present study is consistent with previous work where the duration of clinical symptoms and Treg cell number were measured; these studies did not find a significant correlation between these two parameters [30].

The discrepancy among all of these studies, including the current results, may related to differences in study population, study design, Treg phenotypes, age of individuals, cumulative exposure to malaria, clinical outcome of the disease, working conditions, clinical outcome, among others variables.

There are several important limitations of this study. First, pro- and anti-inflammatory cytokines associated with the regulation by Tregs were not measured. The concept that transmission intensity influences the efficiency of acquiring malaria-specific immunological memory has been reported widely. If the majority of infections occur within a sub-population who frequently travel or live in higher transmission regions (i.e. Africa), then these highly exposed individuals might receive the quantity of infections conventionally considered necessary develop protective immunity against symptoms during infection. Conversely, if infections are acquired locally, then there would be low transmission in the whole population and one would expect most of the infections to be symptomatic. This expectation is based upon literature regarding the development of naturally acquired immunity to $P$. falciparum malaria requiring frequent infections over a period of five years and sustained frequent infections in order to maintain an ability to resist symptoms during malaria infection. With these data the function of Tregs might be different in these regions because of different transmission context, intensity and other unknown factors. Another important consideration is that patients with symptomatic parasitaemia might only have had incidental parasitemia along with a separate concomitant infection responsible for causing the fever; we did not assess this possibility in this study.

The present work is the first to report about number and proportion of Tregs in symptomatic vs. asymptomatic $P$. falciparum infected individuals from a malaria hypoendemic region, typified by the transmission patterns founds in the Peruvian Amazon region. Deeper phenotypic and functional characterization of Tregs in malaria in this and comparable regions may yield new insights into the immunological control of malaria symptomatology in the face of asymptomatic parasitaemia.

\section{Competing interests}

The authors declare that they have no competing interests.

\section{Authors' contributions}

$\mathrm{KT}$ designed the study, carried out the immunological analysis and wrote the paper. EV and JB performed some experiments and contribute to the paper writing. JCH carried out the statistical analysis. JV and DG supervised the work and study design, wrote and reviewed the final versions of the manuscript. All authors read and approved the final manuscript.

\section{Acknowledgments}

We thank the health technicians Mr. Roy Tenorio and Mr. Daniel Sanchez for their support and dedication in the pursuit of patients and sampling. This work was supported by a grant from the International Society of Infectious Diseases (ISID), and United States Public Health Service grants 1D43TW007120, R01Al067727, 1U19AI089681, and 1K24AI068903 (JMV).

\section{Author details}

${ }^{1}$ Instituto de Medicina Tropical "Alexander Von Humboldt", Universidad Peruana, Cayetano Heredia, AP 4314, Lima 100, Peru. Departamento de Ciencias Celulares y Moleculares, Laboratorios de Investigación y Desarrollo, Facultad de Ciencias y Filosofía, Universidad Peruana Cayetano Heredia, AP 4314, Lima 100, Peru. ${ }^{3}$ Division of Infectious Diseases, Department of Medicine, University of California San Diego, La Jolla, CA, USA.

Received: 16 September 2013 Accepted: 14 March 2014 Published: 19 March 2014

\section{References}

1. Marsh K, Forster D, Waruiru C, Mwangi I, Winstanley M, Marsh V, Newton C Winstanley P, Warn P, Peshu N, Pasvol G, Snow R: Indicators of life-threatening malaria in African children. N Engl J Med 1995, 332:1399-1404. 
2. World Health Organization, Division of Control of Tropical Diseases: Severe and complicated malaria. Trans R Soc Trop Med Hyg 1990, 84 Suppl 2:1-65.

3. Roshanravan B, Kari E, Gilman RH, Cabrera L, Lee E, Metcalfe J, Calderon M, Lescano AG, Montenegro SH, Calampa C, Vinetz JM: Endemic malaria in the Peruvian Amazon region of Iquitos. Am J Trop Med Hyg 2003, 69:45-52.

4. Alves FP, Gil LH, Marrelli MT, Ribolla PE, Camargo EP, Da Silva LH: Asymptomatic carriers of Plasmodium spp. as infection source for malaria vector mosquitoes in the Brazilian Amazon. J Med Entomol 2005 42:777-779.

5. Branch O, Casapia WM, Gamboa DV, Hernandez JN, Alava FF, Roncal N, Alvarez E, Perez EJ, Gotuzzo E: Clustered local transmission and asymptomatic Plasmodium falciparum and Plasmodium vivax malaria infections in a recently emerged, hypoendemic Peruvian Amazon community. Malar J 2005, 4:27

6. Vinetz JM, Gilman RH: Asymptomatic Plasmodium parasitemia and the ecology of malaria transmission. Am J Trop Med Hyg 2002, 66:639-640.

7. Brown H, Turner G, Rogerson S, Tembo M, Mwenechanya J, Molyneux M Taylor T: Cytokine expression in the brain in human cerebral malaria. $J$ Infect Dis 1999, 180:1742-1746.

8. Porta J, Carota A, Pizzolato GP, Wildi E, Widmer MC, Margairaz C, Grau GE: Immunopathological changes in human cerebral malaria. Clin Neuropathol 1993, 12:142-146.

9. Sakaguchi S, Powrie F: Emerging challenges in regulatory $T$ cell function and biology. Science 2007, 317:627-629.

10. Belkaid Y: Regulatory T cells and infection: a dangerous necessity. Nat ReV Immunol 2007, 7:875-888.

11. Parroche P, Lauw FN, Goutagny N, Latz E, Monks BG, Visintin A, Halmen KA, Lamphier M, Olivier M, Bartholomeu DC, Gazzinelli RT, Golenbock DT: Malaria hemozoin is immunologically inert but radically enhances innate responses by presenting malaria DNA to Toll-like receptor 9. Proc Nat/ Acad Sci U S A 2007, 104:1919-1924.

12. Sharma S, DeOliveira RB, Kalantari $P$, Parroche $P$, Goutagny $N$, Jiang Z, Chan J, Bartholomeu DC, Lauw F, Hall JP, Barber GN, Gazzinelli RT, Fitzgerald KA, Golenbock DT: Innate immune recognition of an AT-rich stem-loop DNA motif in the Plasmodium falciparum genome. Immunity 2011, 35:194-207.

13. Hisaeda H, Tetsutani K, Imai T, Moriya C, Tu L, Hamano S, Duan X, Chou B, Ishida H, Aramaki A, Shen J, Ishii KJ, Coban C, Akira S, Takeda K, Yasutomo K, Torii M, Himeno K: Malaria parasites require TLR9 signaling for immune evasion by activating regulatory T cells. J Immuno/ 2008, 180:2496-2503.

14. Riley EM, Wahl S, Perkins DJ, Schofield L: Regulating immunity to malaria. Parasite Immunol 2006, 28:35-49.

15. Mangold KA, Manson RU, Koay ES, Stephens L, Regner M, Thomson RB Jr, Peterson LR, Kaul KL: Real-time PCR for detection and identification of Plasmodium spp. J Clin Microbiol 2005, 43:2435-2440.

16. Elhassan IM, Hviid L, Satti G, Akerstrom B, Jakobsen PH, Jensen JB, Theander TG: Evidence of endothelial inflammation, $T$ cell activation, and $T$ cell reallocation in uncomplicated Plasmodium falciparum malaria. Am J Trop Med Hyg 1994, 51:372-379.

17. Chuquiyauri R, Paredes M, Penataro P, Torres S, Marin S, Tenorio A, Brouwer KC, Abeles S, Llanos-Cuentas A, Gilman RH, Kosek M, Vinetz JM: Socio-demographics and the development of malaria elimination strategies in the low transmission setting. Acta Trop 2012, 121:292-302.

18. Couper KN, Blount DG, Wilson MS, Hafalla JC, Belkaid Y, Kamanaka M, Flavell RA, de Souza JB, Riley EM: IL-10 from CD4CD25Foxp3CD127 adaptive regulatory $T$ cells modulates parasite clearance and pathology during malaria infection. PLOS Pathog 2008, 4:e1000004

19. Hisaeda H, Maekawa Y, Iwakawa D, Okada H, Himeno K, Kishihara K, Tsukumo S, Yasutomo K: Escape of malaria parasites from host immunity requires CD4+ CD25+ regulatory T cells. Nat Med 2004, 10:29-30.

20. Kossodo S, Monso C, Juillard P, Velu T, Goldman M, Grau GE: Interleukin-10 modulates susceptibility in experimental cerebral malaria. Immunology 1997, 91:536-540.

21. Walther $M$, Jeffries $D$, Finney OC, Njie M, Ebonyi $A$, Deininger $S$, Lawrence $E_{t}$ Ngwa-Amambua A, Jayasooriya S, Cheeseman $1 \mathrm{H}$, Gomez-Escobar N, Okebe J, Conway DJ, Riley EM: Distinct roles for FOXP3 and FOXP3 CD4 T cells in regulating cellular immunity to uncomplicated and severe Plasmodium falciparum malaria. PLoS Pathog 2009, 5:e1000364.

22. Minigo G, Woodberry T, Piera KA, Salwati E, Tjitra E, Kenangalem E, Price RN, Engwerda CR, Anstey NM, Plebanski M: Parasite-dependent expansion of
TNF receptor II-positive regulatory T cells with enhanced suppressive activity in adults with severe malaria. PLoS Pathog 2009, 5:e1000402.

23. Hansen DS, Schofield L: Natural regulatory T cells in malaria: host or parasite allies? PLoS Pathog 2010, 6:e1000771.

24. Scholzen A, Minigo G, Plebanski M: Heroes or villains? T regulatory cells in malaria infection. Trends Parasitol 2010, 26:16-25.

25. Goncalves RM, Salmazi KC, Santos BA, Bastos MS, Rocha SC, Boscardin SB, Silber AM, Kallas EG, Ferreira MU, Scopel KK: CD4+ CD25+ Foxp3+ regulatory $\mathrm{T}$ cells, dendritic cells, and circulating cytokines in uncomplicated malaria: do different parasite species elicit similar host responses? Infect Immun 2010, 78:4763-4772.

26. Jangpatarapongsa K, Chootong P, Sattabongkot J, Chotivanich K, Sirichaisinthop J, Tungpradabkul S, Hisaeda H, Troye-Blomberg M, Cui L, Udomsangpetch R: Plasmodium vivax parasites alter the balance of myeloid and plasmacytoid dendritic cells and the induction of regulatory T cells. Eur J Immunol 2008, 38:2697-2705.

27. Bueno LL, Morais CG, Araujo FF, Gomes JA, Correa-Oliveira R, Soares IS, Lacerda MV, Fujiwara RT, Braga EM: Plasmodium vivax: induction of CD4 + $\mathrm{CD} 25$ + FoxP3 + regulatory T cells during infection are directly associated with level of circulating parasites. PLoS One 2010, 5:e9623.

28. Torcia MG, Santarlasci V, Cosmi L, Clemente A, Maggi L, Mangano VD, Verra F, Bancone G, Nebie I, Sirima BS, Liotta F, Frosali F, Angeli R, Severini C, Sannella AR, Bonini P, Lucibello M, Maggi E, Garaci E, Coluzzi M, Cozzolino F, Annunziato F, Romagnani S, Modiano D: Functional deficit of T regulatory cells in Fulani, an ethnic group with low susceptibility to Plasmodium falciparum malaria. Proc Natl Acad Sci U S A 2008, 105:646-651.

29. Wammes LJ, Wiria AE, Toenhake CG, Hamid F, Liu KY, Suryani H, Kaisar MM, Verweij JJ, Sartono E, Supali T, Smits HH, Luty AJ, Yazdanbakhsh M: Asymptomatic plasmodial infection is associated with increased tumor necrosis factor receptor ii-expressing regulatory t cells and suppressed type 2 immune responses. J Infect Dis 2013, 207:1590-1599.

30. Farouk SE, Dolo A, Bereczky S, Kouriba B, Maiga B, Farnert A, Perlmann H, Hayano M, Montgomery SM, Doumbo OK, Troye-Blomberg M: Different antibody- and cytokine-mediated responses to Plasmodium falciparum parasite in two sympatric ethnic tribes living in Mali. Microbes Infect 2005, 7:110-117.

\section{doi:10.1186/1475-2875-13-108}

Cite this article as: Torres et al:: Relationship of regulatory $T$ cells to Plasmodium falciparum malaria symptomatology in a hypoendemic region. Malaria Journal 2014 13:108.

\section{Submit your next manuscript to BioMed Central and take full advantage of:}

- Convenient online submission

- Thorough peer review

- No space constraints or color figure charges

- Immediate publication on acceptance

- Inclusion in PubMed, CAS, Scopus and Google Scholar

- Research which is freely available for redistribution 